\title{
Rights for resilience: food sovereignty, power, and resilience in development practice
}

\author{
Marygold Walsh-Dilley ${ }^{1}$, Wendy Wolford ${ }^{2}$ and James McCarthy ${ }^{3}$
}

\begin{abstract}
Even as resilience thinking becomes evermore popular as part of strategic programming among development and humanitarian organizations, uncertainty about how to define, operationalize, measure, and evaluate resilience for development goals prevails. As a result, many organizations and institutions have undertaken individual, collective, and simultaneous efforts toward clarification and definition. This has opened up a unique opportunity for a rethinking of development practices. The emergent consensus about what resilience means within development practice will have important consequences both for development practitioners and the communities in which they work. Incorporating resilience thinking into development practice has the potential to radically transform this arena in favor of social and environmental justice, but it could also flounder as a way to dress old ideas in new clothes or, at worst, to further exploit, disempower, and marginalize the world's most vulnerable populations. We seek to make an intervention into the definitional debates surrounding resilience that supports the former and helps prevent the latter. We argue that resilience thinking as it has been developed in social-ecological systems and allied literatures has a lot in common with the concept of food sovereignty and that paying attention to some of the lessons and claims of food sovereignty movements could contribute toward building a consensus around resilience that supports social and environmental justice. In particular, the food sovereignty movement relies on a strategy that elevates rights. We suggest that a rights-based approach to resilience-oriented development practice could contribute to its application in just and equitable ways.
\end{abstract}

Key Words: development; food sovereignty; human rights; resilience; social justice

\section{INTRODUCTION}

Resilience is an increasingly popular framework for thinking about rural development, particularly among development agencies, policy makers, and practitioners. It is a response to the perception that increased volatility, both social and ecological, but especially climatic, is a key challenge for development. Resilience thinking is seen as a dynamic framework for highlighting interactions and linkages between divisions that often prevail in development work: between the social and ecological, between ongoing development work and acute humanitarian or disaster response, and between systems at different scales (Walsh-Dilley et al. 2013, Sellberg et al. 2015). It also provides a way to focus on and reinforce the positive capabilities and opportunities that abound even in highly constrained or challenged contexts, looking at vulnerable populations not simply for what they lack but also for the creative and situationally appropriate skills and knowledge they possess (Luthar and Cicchetti 2000, Luthar et al. 2000, Masten 2001, Miller et al. 2010).

Despite its widespread and enthusiastic use, there is little consensus regarding a definition of resilience for use in development practice or about what factors contribute to resilience households, communities, or regions (Brand and Jax 2007, MacKinnon and Derickson 2013). In the ecology literature, resilience is defined as "the capacity of a system to experience shocks while retaining essentially the same function, structure, feedbacks, and therefore identity" (Walker et al. 2006; see also Walker et al. 2004, Folke 2006). Adaptation is identified as the key mechanism of resilience (Gunderson and Holling 2002, Folke 2006, Folke et al. 2010, Pendall et al. 2010, Gunderson and Folke
2011). Although for social-ecological system (SES) theory resilience is neither intrinsically positive nor negative, indeed, undesirable system states can be very resilient, development practitioners use resilience in a normative sense. Building adaptive capacity is often taken as a central goal, for example, in the Hyogo Framework for Action 2005-2015: Building the Resilience of Nations and Communities to Disaster (UNISDR 2005). Nonetheless, putting this into practice has proved difficult. For practitioners, it is unclear how to bound these systems to target recipients of aid or support. There is little advice in the scholarly literature about how to identify the scale at which resiliencebuilding activities should focus. There is also no consensus as to what sort of hazards or development challenges should be prioritized in resilience-building efforts. As a result, the resilience concept is used in a wide variety of ways in development practice (see Table 1; also Walsh-Dilley et al. 2013).

To build consensus around resilience, development agencies, organizations, and practitioners have embarked on individual, cross-institutional, and simultaneous efforts toward clarification and definition. This process of collective deliberation has opened up unique opportunities for a rethinking of development practices by generating broad discussion of what really matters for development and how to prioritize it. The emergent consensus about what resilience means within development practice will have important consequences both for development practitioners and the communities in which they work. Incorporating resilience thinking into development practice has the potential to radically transform this arena in favor of social and environmental justice, but it could also flounder as a way to dress old ideas in new clothes or, at worst, to further exploit, disempower, and marginalize the

${ }^{1}$ Honors College, University of New Mexico, ${ }^{2}$ Department of Development Sociology, Cornell University, ${ }^{3}$ Graduate School of Geography, Clark University 
Table 1. Approaches to resilience among select development institutions.

\begin{tabular}{|c|c|c|}
\hline Institution & Definitional Emphasis & Supporting Actions \\
\hline The World Bank ${ }^{\dagger}$ & $\begin{array}{l}\text { The ability to withstand, recover from, and reorganize in } \\
\text { response to crisis so that all members of society may thrive; } \\
\text { forward moving }\end{array}$ & $\begin{array}{l}\text { Community-driven development approaches; enhancing } \\
\text { social learning; increase diversity of livelihood options; } \\
\text { focus on gender equity }\end{array}$ \\
\hline $\begin{array}{l}\text { U.S. Agency for } \\
\text { International } \\
\text { Development }\end{array}$ & $\begin{array}{l}\text { Facilitating resilience processes rather than outcomes; } \\
\text { integrates livelihoods, disaster risk reduction, and climate } \\
\text { change approaches }\end{array}$ & $\begin{array}{l}\text { Forge partnerships between complementary actors; } \\
\text { implement projects at sufficient scale/time horizon; } \\
\text { promote healthy ecosystems; support effective governance; } \\
\text { promote gender equity; support social protection } \\
\text { programs }\end{array}$ \\
\hline $\begin{array}{l}\text { Food and Agriculture } \\
\text { Organization of the } \\
\text { United Nations (FAO) }\end{array}$ & Resilience to food security shocks; emphasis on stability & $\begin{array}{l}\text { Measurement tool: income and food access, access to basic } \\
\text { services, social safety nets, assets, adaptive capacity, } \\
\text { stability }\end{array}$ \\
\hline World Resources & Ecosystem approach to wealth creation and resilience; & Ownership; capacity; connections \\
\hline Institute (WRI) & scaling up of nature-based enterprises & $\begin{array}{l}\text { Enabling environment: supportive policy, tax, and } \\
\text { regulatory environment; technical, research, and marketing } \\
\text { support; financial services/funding }\end{array}$ \\
\hline Oxfam ${ }^{\pi}$ & $\begin{array}{l}\text { "People-centered resilience"; building on the rights of } \\
\text { vulnerable farmers to address key institutional issues within } \\
\text { the agricultural system; risk reduction }\end{array}$ & $\begin{array}{l}\text { Restoring and diversifying natural resources; building } \\
\text { responsive institutions; sustainable livelihood options; } \\
\text { gender equality; farmer-driven decision making } \\
\text { Manage four risks: community risk, productive risk } \\
\text { taking, risk transfer, risk reserves }\end{array}$ \\
\hline CARE International $^{\#}$ & $\begin{array}{l}\text { Community-based adaptation; "building resilience ... from } \\
\text { the ground up"; equity, especially gender equity }\end{array}$ & $\begin{array}{l}\text { Reduce the risk of climate-related disasters; rejuvenate } \\
\text { traditional knowledge; diversify income sources; enhance } \\
\text { local capacity; protection of rights; address underlying } \\
\text { causes of climate vulnerability }\end{array}$ \\
\hline $\begin{array}{l}\text { The World Bank (2012 } \\
{ }^{+} \text {Frankenberger et al. (2 } \\
\text { FAO (date unknown), } \\
\text { WRI et al. (2008) } \\
\text { W Oxfam International (2 } \\
\text { research-publications/ho }\end{array}$ & $\begin{array}{l}\text { Robin Mearns (15 November 2012, personal communication) } \\
\text { 12) } \\
\text { linovi et al. (2010) }\end{array}$ & $\begin{array}{l}\text { project information (http://www.oxfamamerica.org/explore/ } \\
\text { t-july-2011september-2011/) }\end{array}$ \\
\hline
\end{tabular}

world's most vulnerable populations. We seek to make an intervention into the definitional debates surrounding resilience that supports the former and helps prevent the latter.

We argue that resilience thinking as it has been developed in SESs and allied literatures has a lot in common with the concept of food sovereignty that has been developed by peasant and agrarian social movements around the world. Food sovereignty is the idea that people have the right to define their own food and agricultural systems in culturally and ecologically appropriate ways (Vía Campesina 2009). It emphasizes equitable localized control over and knowledge about food systems, including resources for food production such as land and water. Food sovereignty holds in common with the resilience framework a commitment to take seriously the interdependence between social and ecological systems, to local or decentralized governance and natural resource management, and to building local and lay knowledge, skills, and capacities. Yet although resilience thinking has been embraced within development circles, food sovereignty has been largely ignored. We suggest that paying attention to some of the lessons and claims around food sovereignty could contribute toward building a consensus around resilience that supports social and environmental justice. In particular, food sovereignty movements use the language of rights to indicate that people should be able to have more control over the management and government of food and agricultural systems, a prime site for social-ecological interaction.
One of the most salient critiques of the resilience framework deployed in development practice thus far is that it fails to adequately account for relations of power or the contradictory dynamics of capitalist accumulation (Watts 2011:87-88). An apolitical deployment of resilience leaves unexamined those structures and processes that generate vulnerability in the first place and could be used as a justification to blame those who are most vulnerable and least able to marshal the resources necessary for developing resilient trajectories. Although resilience scholarship increasingly asks the questions of resilience by whom, to what, and for what purposes, ${ }^{[1]}$ there remains little attention paid to how these questions are themselves a terrain of contestation and to the fact that some voices, interests, and knowledges are privileged over others (Leach et al. 2010).

SES resilience scholarship has been criticized for weakly theorizing social relations such as power (Miller et al. 2010, Cote and Nightingale 2012), but these problems become particularly conspicuous in the deployment of resilience in development practice. Yet where resilience frameworks undertheorize power, food sovereignty is essentially and explicitly political (Windfuhr and Jonsén 2005). Indeed, this may account for why it has been sidelined in development circles. However, we suggest that lessons from food sovereignty movements can help to integrate power into resilience thinking. We highlight, in particular, the food sovereignty movements' use of rights as a legitimizing strategy 
and argue that a rights-based approach to resilience could invigorate resilience in socially and ecologically just ways. We argue, in particular, that adaptive capacity, and therefore resilience, relies on access to resources including natural, social, political, and economic, and that one significant way to build resilience is to ensure rights to these basic resources. Emphasizing rights for resilience, we suggest, would go a long way toward recognizing that resilience knowledge and practice is political and toward protecting the poor, vulnerable, and silent actors, both human and natural, from exploitation and further marginalization.

Food and agricultural production provides a key site for humannature interactions. Some resilience scholarship has focused on how alternative, marginal, or informal food production and resources, such as Landraces (Zimmerer 2014), wild edible plants (Shumsky et al. 2014), adaption strategies of prehistoric smallscale farmers (Spielmann et al. 2011), and farmers markets (Milestad et al. 2010), contribute to building resilience. Other work has looked in a different direction, at how resilience concepts and frameworks can encourage sustainable land-use change in agriculture (Jansson and Polasky 2010, Pleininger and Bieling 2013). Recently, Sellberg et al. (2015) used the practical tools in the Assessing Resilience in Social-Ecological Systems workbook (Resilience Alliance 2010) to understand sustainability challenges that were not addressed in normal municipal food security planning and operations. Nonetheless, it is perhaps surprising that food and agriculture has thus far not been a significant focus of SES resilience scholarship, particularly the work focused on resilience assessment and capacity building. Because agriculture is a critical space of human-nature interaction and food security is a principal goal of development, food and agriculture is an important yet understudied topic in resilience scholarship.

In what remains of this synthesis essay, we briefly review resilience thinking as it has developed in various disciplines, identify some of its key lessons for development, and outline the most salient critiques of the application of resilience thinking to development practice, namely, in relation to how issues of power are addressed. We then look at how power has been integrated within resilience scholarship but suggest that more is to be done. We introduce food sovereignty and its potential to invigorate this integration.

\section{RESILIENCE THINKING FOR DEVELOPMENT}

SES theories from the field of ecology have exerted the strongest influence on the resilience frameworks in contemporary development policy and practice. This literature emerged from Holling's (1973) seminal work on resilience, which suggests that ecosystems are best thought of as characterized by change and adaptation, multiple possible equilibria, and nonlinear development. Disturbances are an integral part of development, and threats and hazards can provide windows of opportunity for novelty and innovation (Folke 2006, Folke et al. 2010). Thus, Folke (2006) calls SES resilience theory the "science of surprise." A resilient system is able to cope with unexpected changes and disturbances through adaptation (Gunderson and Holling 2002, Folke 2006, Folke et al. 2010, Pendall et al. 2010, Gunderson and Folke 2011). It might not perform as well as others, but it is less vulnerable to shocks, and its performance will not decline as readily when subjected to disturbances (Andereis et al. 2004).
This work initiated a "new ecology" (Zimmerer 1994, Scoones 1999), with far-reaching epistemological and practical implications. In contrast to old approaches of top-down, command-and-control optimization strategies, the knowledge, experience, and skills that contribute to innovation and adaptation come from a variety of sources (Scoones 1999, Andereis et al. 2006, Folke 2006). Indeed, the SES resilience framework privileges local skills, experiences, and knowledge. Adaptability, or the ability to respond to disturbances, requires a capacity among actors within the system to learn and selforganize, and lay and local sources may be better able to respond to shocks quickly, flexibly, and in a contextually appropriate manner (Folke et al. 2010). Even the idea of expertise is suspect; the certainty of unexpected future disturbances to a system means that scientific expertise must be conceived of as provisional, incomplete, and fragmentary (see Scoones 1999). Newer ecological perspectives based on resilience thinking emphasize informal, on-the-ground adaptive management, and variability, flexibility, and heterogeneity are expected to lead to a greater likelihood of system persistence and resilience (Holling 1978, Scoones 1999, Folke et al. 2010).

In development practice, social-ecological framings of resilience are complemented by work in psychology and disaster studies. For example, a shift toward positive psychology and psychological resilience encourages a focus on strengths and competencies of individuals, rather than just treating maladjustment and deficiencies (Luthar and Cicchetti 2000, Luthar et al. 2000, Masten 2001). The disaster studies field focuses on prevention and mitigation, where understanding, managing, and reducing disaster risk is seen as the key to building resilience (CINRHD 2012, IPCC 2012). In line with SES resilience, recent work in this field argues that hazard mitigation is improved when site-specific, indigenous knowledge and scientific knowledge are integrated and when top-down strategies are linked with grassroots strategies and local government intervention (Mercer 2010, Mercer et al. 2010).

These resilience frameworks have the potential to make a significant contribution to development policy and practice. Resilience thinking is holistic, taking an ecological approach that recognizes the linkages between various systems, actors, and "actants" (Latour 2004), bridging, in particular, the socialecological divide. At the same time as resilience thinking casts a wider net in particular places, it also engages with cross-scalar interactions, recognizing that particular actors or sets of actors and actions exist within larger systems and paying attention to how interactions emerge across time. This is a productive counter to emphases on either local or global development, placing, for instance, community-driven development within a nested set of smaller and larger systems. Resilience thinking also has the potential to bridge the humanitarian-development divide, potentially linking relief and development efforts by emphasizing how poverty or lack of resources can exacerbate vulnerabilities to natural and social disasters.

However, there are also some significant concerns about the application of resilience thinking to development practice. An important critique comes out of political ecology and vulnerability scholarship, a tradition in the social sciences that 
also seeks to link society and ecology, arguing that nature is always produced by and through human relationships. This perspective finds that there is very little that is purely "natural" about nature, and that it is instead shaped in the most intimate of ways by social interactions, which are all, at their core, political.

Political ecologists raise this issue of politics and relations of power as a central component of their critique of resilience thinking in development. "What is striking in such an integrated field of theory," geographer Michael Watts writes about resilience thinking, "is that there is no point of intersection between system resiliency and virtually any contemporary account of social power or for that matter the contradictory dynamics of capitalist accumulation" (2011:87-88). Watts argues that this is the danger in attempting to apply complex adaptive systems thinking to social and economic systems, as is done within the resilience school. Systems thinking can have the tendency to treat social dynamics as operating far more deterministically than they actually do, foreclosing the potential of human agency and depoliticizing these same social dynamics by treating them as inevitable rather than as objects of struggle. The SES resilience assumption that disturbances and threats are external and unknown, for example, forestalls the possibility that these threats are frequently related to social phenomena that are both explicable and potentially alterable through action. Thus, Claudia Aradau (2014) argues that resilience's "episteme of surprise" divorces current circumstances from an analysis of historical conditions and constraints that led to them. Such a dehistoricized and depoliticized interpretation of vulnerability limits the possibilities for political action, potentially justifying an abdication of responsibility for the systematic vulnerability of the poor (see also Walker and Cooper 2011, Reid 2012, MacKinnon and Derickson 2013).

Approaches that frame resilience as a personal attribute of individuals or groups are particularly problematic if they fail to recognize the ways in which the environment influences the adaptive capacities of individuals. Such an approach paves the way for perceptions that some people simply do not have what it takes to overcome adversity or toward blaming those who do not possess the characteristics needed (Luthar and Cicchetti 2000, Luthar et al. 2000). This tendency was particularly evident in early approaches to resilience in psychology (see Murray and Zautra 2012, Ungar 2012), but it is also apparent in approaches in international development that use resilience thinking to extend neoliberal ideas into poverty reduction and humanitarian assistance (Watts 2011). The danger, for development policy and practice, of errantly interpreting the concept of resilience as a characteristic of individuals or groups is that it could be construed as a justification to blame those who are most vulnerable and least able to marshal the resources necessary for developing resilient trajectories. Such an approach fails to adequately recognize the ways in which the adaptive capacity of individuals and groups is constrained by a variety of structures and organizations, as well as the entrenched dynamics of power (see Cooper 2008, Reid 2012).

Indeed, the synergies between resilience-oriented development practices and liberal and neoliberal ideologies are readily noted by critics (Cooper 2008, O'Malley 2010, Walker and Cooper 2011, Cote and Nightingale 2012, Reid 2012, Joseph 2013, Aradau
2014). Watts (2011) argues that the rising interest in resilience thinking not only reflects the depth of neoliberal ideology in development but is in fact generative of such thinking. Using the jointly authored report Roots of Resilience (WRI et al. 2008) as a primary example, he argues that the application of resilience to development extends neoliberal ideas into poverty reduction and humanitarian assistance in new ways. This report suggests that markets in ecosystem services are a key mechanism to "create selfinterest that leads to an improved natural resource base," generating "income from sustainably managed ecosystems ... as a stepping stone in the economic empowerment of the poor" (WRI et al. 2008:viii). Not only does such a framework contribute to the expropriation of natural and other resources from poor communities, but Watts argues that resilience in this sense becomes a mechanism of governance within which life becomes nothing more than permanent readiness and flexible adaptation. O'Malley (2010) calls this a "resilience subjectivity." Spontaneous market order has become a form of sustainable development within which any poor person becomes "an entrepreneur of himself,' a hedge-fund manager for his own impoverished life" (Watts 2011:90). The concern is that resilience will be used to justify the further retreat of the state, where poor, vulnerable, and marginalized people and groups are expected to self-organize without the protection, support, and resources of more powerful governance institutions.

These critiques highlight the relations of power at multiple scales. On one hand, they seek to make visible how the assumptions of consensus about and universal benefit of resilience that are pervasive in development policy are flawed (Hornborg 2009, Beymer-Farris et al. 2012). Pursuing resilience necessarily involves trade-offs and compromises at different scales (Coulthard 2012) in what is often a highly uneven process. Second, however, they reveal how resilience may be used to perpetuate ideologies that abdicate state responsibility to the least powerful and discourage collective political action. Making visible the politics of resilience is the first step; the second step it to build conceptualizations of resilience that force us to contend with these tensions, contestations, and relations.

\section{INTEGRATING POWER INTO RESILIENCE THINKING: WHAT FOOD SOVEREIGNTY ADDS}

Recently, in response to such critiques, there has been a notable shift within resilience scholarship as resilience theory has become more diversified and integrative (Miller et al. 2010). Increasingly, attention is paid to issues of power and social differentiation as elements from political ecology, political economy, and vulnerability approaches are integrated into the field (Miller et al. 2010, Ratner et al. 2013, Whaley and Weatherhead 2014). Indeed, practitioner guides, tool kits, and workbooks generated by resilience scholars incorporate power as a central part of assessing and understanding resilience and adaptation. For instance, Assessing Resilience in Social-Ecological Systems: Workbook for Practitioners encourages practitioners to specify resilience by asking "Resilience of what, to what?" and to map power relations and conflicts as part of a resilience assessment (Resilience Alliance 2010:5; see also Resilience Alliance [date unknown], Walker and Salt 2006, 2012). These works have proved useful in conducting resilience assessments on the ground, although they treat power in broad strokes and could do better to provide practical guidance on how to deal with trade-offs and other issues 
(Sellberg et al. 2015). Whaley and Weatherhead (2014) suggest a "politicized" institutional analysis and development framework wherein the broader political economy of a system and the discourses that "sustain or challenge existing power structures" are treated as exogenous variables influencing, in their case, adaptive comanagement. Ratner et al. (2013) suggest paying attention to how power is distributed in SES governance via questioning representation, authority, and accountability.

These recent examples notwithstanding, even scholars within the resilience field suggest that more work is to be done, particularly in relation to informal and unorganized power dynamics and the recognition of social diversity and related conflicts (Vink et al. 2013, Fabinyi et al. 2014). Furthermore, the critical scholarship outlined previously pushes us to consider how resilience thinking might lose its systems perspective when taken up by development practitioners, using the "episteme of surprise" (Aradau 2014) and valuation of lay and indigenous knowledge to individualize adaptive capacity building.

Thus, although contemporary development practice might apply resilience in uncritical or apolitical ways, food sovereignty is an explicitly political approach to development (Windfuhr and Jonsén 2005). Food sovereignty is a framework used by agrarian social movements around the world to address issues of poverty, rural underdevelopment, and the domination of the agricultural system by agricultural policies of the United States and Europe. Vía Campesina is the transnational organization behind the food sovereignty concept, bringing together millions of peasants, farmers, rural residents, and agricultural workers from around the world to defend "small-scale sustainable agriculture as a way to promote social justice and dignity" (http://viacampesina.org/ en/index.php/organisation-mainmenu-44). Underlying food sovereignty is the idea that people deserve to live dignified and meaningful lives with suitable livelihoods, not just coping at a basic level. Many agrarian movements use the term "living well" or "a good life" to express this goal. In so doing, social movements struggle against the structural conditions of poverty and insecurity.

The principal contention of food sovereignty is that people should be able to have more control over their own food and agriculture than the current global food system allows. In fact, food sovereignty is defined in terms of "the right of peoples to healthy and culturally appropriate food produced through ecologically sound and sustainable methods and their right to define their own food and agricultural system" (Vía Campesina 2009:673; see also Vía Campesina 1996). It is oriented toward creating food systems that (1) provide sufficient, healthy, nutritious, and culturally appropriate food for all; (2) protect consumers' ability to determine what they consume and how; (3) value and support food providers, with a particular focus on small-scale family farmers and peasants; (4) localize control over and access to natural resources and ensure democratic participation in agricultural policy decision making; (5) protect the access of smallholder farmers, pastoralists, fisherfolk, and landless people to important resources such as land, seeds, livestock breeds, and credit; (6) value and contribute to local knowledge and skills; and (7) value agroecology as a way to achieve environmental integrity and sustainable livelihoods (Windfuhr and Jonsén 2005, Vía Campesina 2009). Clearly, the food sovereignty concept prioritizes local agricultural production and resource governance, emphasizing local autonomy, local markets, and community action (IAASTD 2009), that is, local capacity to produce and consume socially and ecologically appropriate food.

One of the important tools that food sovereignty and other agrarian social movements use to pursue these claims is the framework of rights (Patel 2009, Vía Campesina 2009). This is not just a matter of the right to food itself, but the right to the social, political, and natural resources that allow them to determine and define their own systems of food production and consumption. Patel writes: "If we talk about food sovereignty, we talk about rights, and if we do that, we must talk about ways to ensure those rights are met, across a range of geographies, by everyone, in substantive and meaningful ways" (2009:671). The use of a rights-based framework by food sovereignty movements is strategic on two counts. First, the language of rights available through the United Nations framework has allowed these groups to make disparate claims and concerns more legible to a broader audience and to gain access to dominant political and social institutions (Casas 2011). However, it also allows these social movements to simultaneously sue for greater autonomy and direct control and insist on the state's role in supporting and protecting these claims (McKay et al. 2014). At the same time, however, these social movements are redefining the liberal notion of rights (Kabeer 2002), for example, ascribing rights to nature, to collective or cultural entities, and to food. The strategic use of rights ensures that the focus on local capacity does not devolve into an individualizing logic wherein both the responsibility and blame for poverty are placed on poor people's shoulders without attention to the systems within which poverty comes about and is patterned.

In addition to rights, food sovereignty movements emphasize equity and the equitable distribution of resources and opportunities across populations as both a central goal for food sovereignty and a factor contributing to it. They pay special attention to the most marginalized, vulnerable, or disadvantaged populations, focusing on the structural forms of marginalization embodied in gender, caste, and ethnic relations. Thus, food sovereignty attends to power both across scales, i.e., between local and state institutions, and within them, i.e., attending to differentiation within the local level.

The resilience and food sovereignty frameworks coincide in a number of key ways. Like the resilience framework, the approach championed by food sovereignty movements represents a radical epistemic shift (Ishii-Eiteman 2009, Scoones 1999, Wittman 2011), valuing and privileging the capacities and concerns of local populations. These frameworks thus both advocate for a decentralized governance structure, with direct and close-to-theground resource management. For both, maximizing growth or output is not the goal, but rather sustainability, identity, and buoyancy over the long run are prioritized. They both explicitly recognize the interactions and mutual constitution of natural and social spheres and recognize diversity as a significant asset in protecting these linked systems. Both frameworks incorporate a commitment to equity, food sovereignty very explicitly as a political project and the resilience framework as a recognized contributor of resilience (Nelson et al. 2007). Finally, both frameworks emphasize the processual nature of healthy and 
balanced systems: neither food sovereignty nor resilience is considered a finite or objective outcome, but rather a continually contested process of responding, adaptation, and livelihood making.

However, what food sovereignty and the larger literatures in political ecology and vulnerability studies force us to reckon with is how these processes of adaptation and livelihood making take place within a terrain of power and contestation. This requires us to pay attention to the social structural elements that condition the distribution of resources and opportunities people and systems have for building resilience. A rights-based framework suggests that seeing access to these resources as a matter of rights (rather than markets) will go a long way to ensuring that resilience practice in development addresses the structural, distributional, and political factors shaping adaptive capacities and resilience potential. Rights-based approaches have already been applied to watershed and fisheries management (Allison et al. 2012) and through that linkage are beginning to have an influence in resilience scholarship as well. As Ratner et al. (2013) note: "building social, political and economic rights is an integral element of poverty reduction, and a necessary foundation for efforts to build resilience and adaptive capacity."

\section{CONCLUSION: RESILIENCE FOR SOCIAL JUSTICE}

Centralizing food production, access, and control, as is done in the food sovereignty framework, can help to build a conceptualization of resilience that serves both social and ecological justice. Paying attention to food sovereignty necessarily requires attention to relations of power as a key component for understanding and ultimately building resilience within a development context. A rights-based approach helps us to foreground these issues; people need access to the resources with which they might build resilience. Inspired by food sovereignty, a rights-based framework helps to generate the expectation that all people should have access to the resources they need to build resilience. Although such an approach supports local capacity and governance, it also highlights the role of states and other institutions in social support and protection, meaning resilience will not ever be used as justification to blame the poor or abdicate responsibility to them.

There are several corollaries to a rights-based approach to resilience, some of which have already been highlighted in the resilience and critical literature but have not always been translated into development practice. First, equity is central to a responsible, social-justice approach to resilience (Nelson et al. 2007, Bahadur et al. 2010). Lack of equity is not just an outcome of failed resilience; inequality itself diminishes the possibilities for resilience building. Of course, how we measure equity in this context and how much equity is necessary are questions deserving of more research. Second, to build resilience in a particular context, we cannot just look forward but must also look back to understand what social structures and relations of power have created contemporary outcomes. That is, we must understand the social and political structures that facilitate or inhibit resilience, those formal and informal mechanisms through which power flows (Watts 2011, Reid 2012). Supporting resilience involves efforts to uncover and work against the root causes of vulnerability and poverty, and efforts to support individual and group adaptive capacity must be accompanied by efforts aimed at structural change. Third, resilience is a contested process, both in terms of the priorities and distribution of benefits within particular locations and with regard to how it is defined and put into practice (Leach et al. 2010). There are multiple actors in any given community and across scales with different ideas about the form of resilience that is most desirable. People are in different positions with varying abilities to pursue resilience.

Food sovereignty attends to these issues through the language of rights, namely, that people must have the right to define their own food and agricultural system, which means, of course, that their rights to the resources necessary to do so must be protected. Similarly, we argue that people must have the rights to the necessary resources to build resilient livelihoods. We have argued elsewhere that there is a broad spectrum of necessary rights for building the adaptive capacities of the poor, including political, ecological, social, and civic rights (Walsh-Dilley et al. 2013). What remains unknown is which particular rights and in which combination are most important. Ostrom (1990) suggests a set of rights necessary for the resilience of common property institutions, including the right of participants to contribute to defining the rules of the system and the protected right to organize, both of which we anticipate would contribute to building resilience livelihoods as well. A fruitful future direction of research would be further work that examines which rights are most important for building resilient SESs. This work might ask whether the necessary portfolio of rights varies across agroecological and political systems or which rights are necessary versus sufficient in different SESs. SESs and agroecosystems are very diverse, and different rights may be needed to enhance resilience within these diverse systems. Understanding how rights contribute differentially to resilience across these systems would contribute to our ability to integrate resilience thinking into development practice.

[1] For instance, during the Resilience 2014 conference in Montpellier, France, one of the conference themes was "Whose development, whose resilience?" (see http://www.resilience2014. org; also Cretney 2014).

Responses to this article can be read online at: http://www.ecologyandsociety.org/issues/responses. $\mathrm{php} / 7981$

\section{Acknowledgments:}

This article builds on a collaboration we undertook with Oxfam America, and we would like to thank our partners there, particularly Kimberly Pfeifer and Gina Castillo, as well as the participants of the Invited Experts' Meeting on Resilience, hosted by Oxfam America on 8 March 2013. Our gratitude also goes to two anonymous reviewers and the editors of Ecology and Society for excellent suggestions for improving this manuscript, as well as Elisa daVia and Sara Keene for careful research assistance. This project was funded in part by the Atkinson Center for a Sustainable Future at Cornell University. 


\section{LITERATURE CITED}

Alinovi, L., E. Mane, and D. Romano. 2010. Measuring household resilience to food insecurity: application to Palestinian households. Pages 341-368 in R. Benedetti, M. Bee, G. Espa, and F. Piersimoni, editors. Agricultural survey methods. John Wiley and Sons, Chichester, UK. http://dx.doi.org/10.1002/9780470665480. $\underline{\operatorname{ch} 21}$

Allison, E. H., B. D. Ratner, B. Asgård, R. Willmann, R. Pomeroy, and J. Kurien. 2012. Rights-based fisheries governance: from fishing rights to human rights. Fish and Fisheries 13(1):14-29. http://dx.doi.org/10.1111/j.1467-2979.2011.00405.x

Andereis, J. M., M. A. Janssen, and E. Ostrom. 2004. A framework to analyze the robustness of social-ecological systems from an institutional perspective. Ecology and Society 9(1):18. [online] URL: http://www.ecologyandsociety.org/vo19/iss1/art18/

Andereis, J. M., B. H. Walker, and A. P. Kinzig. 2006. Fifteen weddings and a funeral: case studies and resilience-based management. Ecology and Society 11(1):21. [online] URL: http:// www.ecologyandsociety.org/vol11/iss1/art21/

Aradau, C. 2014. The promise of security: resilience, surprise and epistemic politics. Resilience: International Policies, Practices and Discourses 2(2):73-87. http://dx.doi.org/10.1080/21693293.2014.914765

Bahadur, A. V., M. Ibrahim, and T. Tanner. 2010. The resilience renaissance? Unpacking of resilience for tackling climate change and disasters. Strengthening Climate Resilience Discussion Paper 1. Institute of Development Studies, Brighton, UK.

Beymer-Farris, B. A., T. J. Bassett, and I. Bryceson. 2012. Promises and pitfalls of adaptive management in resilience thinking: the lens of political ecology. Pages 283-300 in T. Plieninger and C. Bieling, editors. Resilience and the cultural landscape: understanding and managing change in human-shaped environments. Cambridge University Press, Cambridge, UK. http://dx.doi.org/10.1017/cbo9781139107778.020

Brand, F. S., and K. Jax. 2007. Focusing the meaning(s) of resilience: resilience as a descriptive concept and a boundary object. Ecology and Society 12(1):23. [online] URL: http://www. ecologyandsociety.org/vol12/iss1/art23/

Casas, T. 2011. Indigenous ontologies and expanding political frontiers. In Proceedings of the Annual Meeting of the American Sociological Association (Las Vegas, Nevada, 19 August 2011). American Sociological Association, Washington, D.C., USA.

Committee on Increasing National Resilience to Hazards and Disasters of the National Academy of Sciences (CINRHD). 2012. Disaster resilience: a national imperative. National Academy of Sciences, Washington, D.C., USA.

Cooper, M. 2008. Life as surplus: biotechnology and capitalism in the neoliberal era. Washington University Press, Seattle, Washington, USA.

Cote, M., and A. J. Nightingale. 2012. Resilience thinking meets social theory: situating social change in socio-ecological systems (SES) research. Progress in Human Geography 36(4):475-489. http://dx.doi.org/10.1177/0309132511425708

Coulthard, S. 2012. Can we be both resilient and well, and what choices do people have? Incorporating agency into the resilience debate from a fisheries perspective. Ecology and Society 17(1):4. http://dx.doi.org/10.5751/es-04483-170104

Cretney, R. 2014. Resilience for whom? Emerging critical geographies of socio-ecological resilience. Geography Compass 8 (9):627-640. http://dx.doi.org/10.1111/gec3.12154

Fabinyi, M., L. Evans, and S. J. Foale. 2014. Social-ecological systems, social diversity, and power: insights from anthropology and political ecology. Ecology and Society 19(4):28. http://dx.doi. org/10.5751/es-07029-190428

Folke, C. 2006. Resilience: the emergence of a perspective for social-ecological systems analysis. Global Environmental Change 16:253-267. http://dx.doi.org/10.1016/j.gloenvcha.2006.04.002

Folke, C., S. R. Carpenter, B. Walker, M. Scheffer, T. Chapin, and J. Rockström. 2010. Resilience thinking: integrating resilience, adaptability and transformability. Ecology and Society 15(4):20. [online] URL: http://www.ecologyandsociety.org/vol15/iss4/ $\underline{\operatorname{art} 20 /}$

Food and Agriculture Organization of the United Nations (FAO). [date unknown]. Measuring resilience: a concept note on the resilience tool. Food Security Information for Decision Making Concept Note. FAO, Rome, Italy. [online] URL: http://www.fao. org/docrep/013/a1920e/a1920e00.pdf

Frankenberger, T., M. Langworthy, T. Spangler, and S. Nelson. 2012. Enhancing resilience to food security shocks. White paper (draft). Tango International Inc., Tucson, Arizona, USA. [online] URL: http://www.fsnnetwork.org/sites/default/files/

revised_resilience_paper_may_28.pdf

Gunderson, L., and C. Folke. 2011. Resilience 2011: leading transformational change. Ecology and Society 16(2):30. [online] URL: http://www.ecologyandsociety.org/vol16/iss2/art30/

Gunderson, L., and C. S. Holling, editors. 2002. Panarchy: understanding transformations in human and natural systems. Island, Washington, D.C., USA.

Holling, C. S. 1973. Resilience and stability of ecological systems. Annual Review of Ecological Systems 4:1-23. http://dx.doi. org/10.1146/annurev.es.04.110173.000245

Holling, C. S. 1978. Adaptive environmental assessment and management. Wiley, London, UK.

Hornborg, A. 2009. Zero-sum world: challenges in conceptualizing environmental load displacement and ecologically unequal exchange in the world-system. International Journal of Comparative Sociology 50(3-4):237-262. http://dx.doi. org/10.1177/0020715209105141

International Assessment of Agricultural Knowledge, Science and Technology for Development (IAASTD). 2009. Agriculture at a crossroads: synthesis report. Island, Washington, D.C., USA.

IPCC. 2012. Managing the risks of extreme events and disasters to advance climate change adaptation. A Special Report of Working Groups I and II of the Intergovernmental Panel on Climate Change. Cambridge University Press, Cambridge, UK. [online] URL: http://ipcc-wg2.gov/SREX/images/uploads/SREX-All_FINAL. pdf 
Ishii-Eiteman, M. 2009. Food sovereignty and the international assessment of agricultural knowledge, science, and technology for development. Journal of Peasant Studies 36(3):689-700.

Jansson, Å., and S. Polasky. 2010. Quantifying biodiversity for building resilience for food security in urban landscapes: getting down to business. Ecology and Society 15(3):20. [online] URL: http://www.ecologyandsociety.org/vol15/iss3/art20/

Joseph, J. 2013. Resilience as embedded neoliberalism: a governmentality approach. Resilience: International Policies, Practices and Discourses 1(1):38-52. http://dx.doi. org/10.1080/21693293.2013.765741

Kabeer, N. 2002. 'We don't do credit': Nijera Kori, social mobilisation and the collective capabilities of the poor in rural Bangladesh. Nijera Kori, Dhaka, Bangladesh.

Latour, B. 2004. Politics of nature: how to bring the sciences into democracy. Harvard University Press, Cambridge, Massachusetts, USA.

Leach, M., I. Scoones, and A. Stirling. 2010. Dynamic sustainabilities: technology, environment, social justice. Earthscan, London, UK.

Luthar, S. S., and D. Cicchetti. 2000. The construct of resilience: implications for interventions and social policies. Development and Psychopathology 12(4):857-885. http://dx.doi.org/10.1017/ $\underline{\mathrm{s} 0954579400004156}$

Luthar, S. S., D. Cicchetti, and B. Becker. 2000. The construct of resilience: a critical evaluation and guidelines for future work. Child Development 71(3):543-562. http://dx.doi.org/10.1111/1467-8624.00164

MacKinnon, D., and K. D. Derickson. 2013. From resilience to resourcefulness: a critique of resilience policy and activism. Progress in Human Geography 37(2):253-270. http://dx.doi. org/10.1177/0309132512454775

Masten, A. S. 2001. Ordinary magic: resilience processes in development. American Psychologist 56(3):227-238. http://dx. doi.org/10.1037/0003-066x.56.3.227

McKay, B., R. Nehring, and M. Walsh-Dilley. 2014. The 'state' of food sovereignty in Latin America: political projects and alternative pathways in Venezuela, Ecuador and Bolivia. Journal of Peasant Studies 41(6):1175-1200. http://dx.doi. org/10.1080/03066150.2014.964217

Mercer, J. 2010. Disaster risk reduction or climate change adaptation: are we reinventing the wheel? Journal of International Development 22:247-264. http://dx.doi.org/10.1002/jid.1677

Mercer, J., I. Kelman, L. Taranis, and S. Suchet-Pearson. 2010. Framework for integrating indigenous and scientific knowledge for disaster risk reduction. Disasters 34(1):214-239. http://dx.doi. org/10.1111/j.1467-7717.2009.01126.X

Milestad, R., L. Westberg, U. Geber, and J. Björklund. 2010. Enhancing adaptive capacity in food systems: learning at farmers' markets in Sweden. Ecology and Society 15(3):29. [online] URL: http://www.ecologyandsociety.org/vol15/iss3/art29/

Miller, F., H. Osbahr, E. Boyd, F. Thomalla, S. Bharwani, G. Ziervogel, B. Walker, J. Birkmann, S. Van der Leeuw, J.
Rockström, J. Hinkel, T. Downing, C. Folke, and D. Nelson. 2010. Resilience and vulnerability: complementary or conflicting concepts? Ecology and Society 15(3):11. [online] URL: http:// www.ecologyandsociety.org/vol15/iss3/art11/

Murray, K., and A. Zautra. 2012. Community resilience: fostering recovery, sustainability, and growth. Pages 337-345 in M. Ungar, editor. The social ecology of resilience: a handbook of theory and practice. Springer, New York, New York, USA. http://dx.doi. org/10.1007/978-1-4614-0586-3 26

Nelson, D. R., W. N. Adger, and K. Brown. 2007. Adaptation to environmental change: contributions of a resilience framework. Annual Review of Environment and Resources 32:395-419. http:// dx.doi.org/10.1146/annurev.energy.32.051807.090348

O’Malley, P. 2010. Resilient subjects: uncertainty, warfare and liberalism. Economy and Society 39(4):488-509. http://dx.doi. org/10.1080/03085147.2010.510681

Ostrom, E. 1990. Governing the commons: the evolution of institutions for collective action. Cambridge University Press, New York, New York, USA. http://dx.doi.org/10.1017/CBO9780511807763

Oxfam International. 2009. People-centred resilience: working with vulnerable farmers towards climate change adaptation and food security. Oxfam Briefing Paper 135. Oxfam International, Oxford, UK.

Patel, R. 2009. What does food sovereignty look like? Journal of Peasant Studies 36(3):663-673. http://dx.doi.org/10.1080/030661$\underline{50903143079}$

Pendall, R., K. A. Foster, and M. Cowell. 2010. Resilience and regions: building understanding of the metaphor. Cambridge Journal of Regions, Economy, and Society 3:71-84. http://dx.doi. org/10.1093/cjres/rsp028

Pleininger, T., and C. Bieling. 2013. Resilience-based perspectives to guiding high-nature-value farmland through socioeconomic change. Ecology and Society 18(4):20. http://dx.doi.org/10.5751/ es-05877-180420

Ratner, B. D., P. Cohen, B. Barman, K. Mam, J. Nagoli, and E. H. Allison. 2013. Governance of aquatic agricultural systems: analyzing representation, power, and accountability. Ecology and Society 18(4):59. http://dx.doi.org/10.5751/es-06043-180459

Reid, J. 2012. The disastrous and politically debased subject of resilience. Development Dialogue 58:67-80.

Resilience Alliance. 2010. Assessing resilience in social-ecological systems: workbook for practitioners. Version 2.0. [online] URL: http://www.redagres.org/Assessing $\% 20$ Resilience $\% 20 \mathrm{in} \% 20$ SocialEcological $\% 20$ Systems.pdf

Resilience Alliance. [date unknown]. Applying a social-ecological inventory: a workbook for finding the key actors and engaging them. [online] URL: http://www.stockholmresilience.org/ download/18.1f74f76413071d337c380004085/1381790163553/RA+ workbook + final.pdf

Scoones, I. 1999. New ecology and the social sciences: what prospects for a fruitful engagement? Annual Review of Anthropology 28:479-507. http://dx.doi.org/10.1146/annurev. anthro.28.1.479 
Sellberg, M. M., C. Wilkinson, and G. D. Peterson. 2015. Resilience assessment: a useful approach to navigate urban sustainability challenges. Ecology and Society 20(1):43. http://dx. doi.org/10.5751/es-07258-200143

Shumsky, S. A., G. M. Hickey, B. Pelletier, and T. Johns. 2014. Understanding the contribution of wild edible plants to rural social-ecological resilience in semi-arid Kenya. Ecology and Society 19(4):34. http://dx.doi.org/10.5751/es-06924-190434

Spielmann, K. A., M. Nelson, S. Ingram, and M. A. Peeples. 2011. Sustainable small-scale agriculture in semi-arid environments. Ecology and Society 16(1):26. [online] URL: http://www. ecologyandsociety.org/vol16/iss1/art26/

Ungar, M. 2012. Social ecologies and their contribution to resilience. Pages 13-31 in M. Ungar, editor. The social ecology of resilience: a handbook of theory and practice. Springer, New York, New York, USA. http://dx.doi.org/10.1007/978-1-4614-0586-3_2

United Nations International Strategy for Disaster Reduction (UNISDR). 2005. The Hyogo framework for action 2005-2015: building the resilience of nations and communities to disasters. UNISDR, Geneva, Switzerland. [online] URL: http://www. unisdr.org/2005/wcdr/intergover/official-doc/L-docs/Hyogo-frameworkfor-action-english.pdf

Vía Campesina. 1996. La Vía Campesina: Proceedings from the II International Conference of the Via Campesina, Tlaxcala, Mexico, April 18-21, 1996. NCOS, Brussels, Belgium.

Vía Campesina. 2009. Nyéléni declaration on food sovereignty: 27 February 2007, Nyéléni Village, Sélingué, Mali. Journal of Peasant Studies 36(3):673-676.

Vink, M. J., A. Dewulf, and C. Termeer. 2013. The role of knowledge and power in climate change adaptation governance: a systematic literature review. Ecology and Society 18(4):46. http:// dx.doi.org/10.5751/es-05897-180446

Walker, J., and M. Cooper. 2011. Genealogies of resilience: from systems ecology to the political economy of crisis adaptation. Security Dialogue 42(2):143-160. http://dx.doi.org/10.1177/0967$\underline{010611399616}$

Walker, B. H., L. H. Gunderson, A. P. Kinzig, C. Folke, S. R. Carpenter, and L. Schultz. 2006. A handful of heuristics and some propositions for understanding resilience in social-ecological systems. Ecology and Society 11(1):13. [online] URL: http://www. ecologyandsociety.org/vol11/iss1/art13/

Walker, B., C. S. Holling, S. R. Carpenter, and A. Kinzig. 2004. Resilience, adaptability and transformability in social-ecological systems. Ecology and Society 9(2):5. [online] URL: http://www. ecologyandsociety.org/vol9/iss2/art5/

Walker, B., and D. Salt. 2006. Resilience thinking: sustaining ecosystems and people in a changing world. Island, Washington, D.C., USA.

Walker, B., and D. Salt. 2012. Resilience practice: building capacity to absorb disturbance and maintain function. Island, Washington, D.C., USA. http://dx.doi.org/10.5822/978-1-61091-231-0

Walsh-Dilley, M., W. Wolford, and J. McCarthy. 2013. Rights for resilience: bringing power, rights and agency into the resilience framework. Atkinson Center for a Sustainable Future (ACSF)Oxfam Working Paper. ACSF, Cornell University, Ithaca, New York, New York, USA. [online] URL: http://www.acsf.cornell. edu/Assets/ACSF/docs/collaborations/oxfam/R4R $\% 20$ Conceptual $\%$ 20Framework.pdf

Watts, M. J. 2011. Ecologies of rule: African environments and the climate of neoliberalism. Pages 67-91 in C. Calhoun and G. Derluguian, editors. The deepening crisis: governance challenges after neoliberalism. New York University, New York, New York, USA.

Whaley, L., and E. K. Weatherhead. 2014. An integrated approach to analyzing (adaptive) comanagement using the "politicized" IAD framework. Ecology and Society 19(1):10. http://dx.doi.org/10.5751/ES-06177-190110

Windfuhr, M., and J. Jonsén. 2005. Food sovereignty: towards democracy in localized food systems. ITDG, Rugby, UK.

Wittman, H. 2011. Food sovereignty: a new rights framework for food and nature? Environment and Society 2(1):87-105.

The World Bank. 2012. What is social resilience? The World Bank, Washington, D.C., USA.

World Resources Institute (WRI), United Nations Development Programme, United Nations Environment Programme, and the World Bank. 2008. World resources 2008: roots of resiliencegrowing the wealth of the poor. WRI, Washington, D.C., USA.

Zimmerer, K. S. 1994. Human geography and the "new ecology": the prospect and promise of integration. Annals of the Association of American Geographers 84(1):108-125. http://dx.doi.org/10.1111/ j.1467-8306.1994.tb01731.x

Zimmerer, K. S. 2014. Conservation agrobiodiversity and global change, migration, and nontraditional livelihood networks: the dynamic uses of cultural landscape knowledge. Ecology and Society 19(2):1. http://dx.doi.org/10.5751/ES-06316-190201 